\title{
High fetal hemoglobin level is associated with increased risk of cerebral vasculopathy in children with sickle cell disease in Mayotte
}

Abdourahim Chamouine ${ }^{1 *}$, Thoueiba Saandi ${ }^{1}$, Mathias Muszlak', Juliette Larmaraud ${ }^{1}$, Laurent Lambrecht', Jean Poisson ${ }^{1}$, Julien Balicchi ${ }^{1}$, Serge Pissard ${ }^{2}$ and Narcisse Elenga ${ }^{3}$

\begin{abstract}
Background: Understanding the genetics underlying the heritable subphenotypes of sickle cell anemia, specific to each population, would be prognostically useful and could inform personalized therapeutics. The objective of this study was to describe the genetic modulators of sickle cell disease in a cohort of pediatric patients followed up in Mayotte.

Methods: This retrospective cohort study analyzed clinical and biological data, collected between January $1{ }^{\text {st }} 2007$ and December $31^{\text {st }} 2017$, in children younger than 18 years.

Results: We included 185 children with 72\% SS, 16\% S $\beta 0$-thalassemia and 12\% S $\beta$ + thalassemia. The average age was 9.5 years; $10 \%$ of patients were lost to follow up. The Bantu haplotype was associated with an increase in hospitalizations and transfusions. The alpha-thalassemic mutation was associated with a decrease of hemolysis biological parameters (anemia, reticulocytes), and a decrease of cerebral vasculopathy. The Single Nucleotide Polymorphisms BCL11A rs4671393, BCL11A rs11886868, BCL11A rs1427407 and HMIP rs9399137 were associated with the group of children with $\mathrm{HbF}>10 \%$. Patients with $\mathrm{HbF}>10 \%$ presented a significant risk of early onset of cerebral vasculopathy.
\end{abstract}

Conclusions: The most remarkable result of our study was the association of SNPs with clinically relevant phenotypic groups. BCL11A rs4671393, BCL11A rs11886868, BCL11A rs1427407 and HMIP rs9399137 were correlated with HbF > $10 \%$, a group that has a higher risk of cerebral vasculopathy and should be oriented towards the hemolytic subphenotype.

Keywords: Sickle cell disease, High hemoglobin level, Cerebral vasculopathy, Children, Single nucleotide polymorphism, Mayotte

\footnotetext{
* Correspondence: a.chamouine1@chmayotte.fr

'Pediatric Unit, Mamoudzou General Hospital, 1, Rue de l'Hopital, BP 4, 97600 Mamoudzou, Mayotte, France

Full list of author information is available at the end of the article
}

(C) The Author(s). 2020 Open Access This article is licensed under a Creative Commons Attribution 4.0 International License, which permits use, sharing, adaptation, distribution and reproduction in any medium or format, as long as you give appropriate credit to the original author(s) and the source, provide a link to the Creative Commons licence, and indicate if changes were made. The images or other third party material in this article are included in the article's Creative Commons licence, unless indicated otherwise in a credit line to the material. If material is not included in the article's Creative Commons licence and your intended use is not permitted by statutory regulation or exceeds the permitted use, you will need to obtain permission directly from the copyright holder. To view a copy of this licence, visit http://creativecommons.org/licenses/by/4.0/. The Creative Commons Public Domain Dedication waiver (http://creativecommons.org/publicdomain/zero/1.0/) applies to the data made available in this article, unless otherwise stated in a credit line to the data. 


\section{Background}

Sickle cell disease (SCD) refers to a group of autosomal recessive genetic disorders characterized by the synthesis of an abnormal hemoglobin: sickle hemoglobin $S\left(\beta^{s}\right.$, $\mathrm{HbS}$ ), results from the substitution of a single amino acid (Glu $\rightarrow$ Val) at the sixth position of $\beta$-chain of normal hemoglobin (HbA) molecule [1, 2]. This singlepoint mutation leads to the polymerization of the $\mathrm{HbS}$ molecule and red cell sickling under deoxygenated conditions. Homozygous SS (sickle cell anemia or SCA) is usually considered the most severe form of SCD. Compound heterozygotes, in whom $\mathrm{HbS}$ is combined with a different mutation in the second $\beta$-globin gene, such as $\mathrm{HbC}, \mathrm{D}, \mathrm{O}^{\mathrm{Arab}}$ or $\beta$-thalassemia (where $\beta$-globin synthesis is reduced) can also be affected, with variable phenotypes. SCD is characterized by abnormally shaped, adhesive red blood cells (RBCs) that interact with white blood cells (WBCs) and the endothelium, leading to chronic hemolysis, vasculopathy and a prothrombotic state [1]. These processes can result in severe complications including chronic pain, downstream-organ dysfunction, stroke, life-long suffering, poor quality of life and early mortality.

The clinical variability of SCD requires searching for factors responsible for its severity, in order to establish a clinical classification according to severity. This classification is useful for optimizing management, and adjusting the follow-up as closely as possible to the real risk presented by each patient. Thus, understanding the genetics underlying the heritable subphenotypes of SCD, specific to each population, would be prognostically useful and could inform customized therapeutics. Numerous studies have been devoted to genetic modulating factors of SCD [3-6]. Fetal hemoglobin (HbF) is the major genetic modulator of the hematologic and clinical features of SCD [7].

Coinheritance of alpha thalassemia trait and SCD is known to decrease the SCD severity. Indeed, alphathalassemia modulates SCD by reducing the intracellular concentration of $\mathrm{HbS}$, which in turn reduces the $\mathrm{HbS}$ polymer induced cellular damage. By the basis of this mechanism, there will be a reduction in hemolysis, stroke, silent infarction, transcranial doppler (TCD) velocity, and acute chest syndrome [8]. The $\beta^{\mathrm{S}}$-mutation is found on five haplotypes, that are named according to their putative geographic origins: Benin, Bantu (Central African), Cameroon, Senegal and Arab-Indian [9]. Many authors have tried to correlate the clinical severity of SCD with the beta globin haplotypes ( $\beta S$ ). Despite some contradictory results, it is generally recognized that the Senegal and Arabic-Indian haplotypes are associated with fewer complications because of higher residual $\mathrm{HbF}$ levels. However, many studies were conducted in populations with only one or two over-represented $\beta S$ haplotypes $[10,11]$.
Other genetic polymorphisms with an established influence on the SCD phenotype have been identified, including, HbF modifiers (XmnI, BCL11A, and HBS1L-MYB polymorphisms), uridine-diphosphoglucuronate glucuronosyltransferase (UGT1A1) promoter polymorphisms, and Glucose-6-phosphate dehydrogenase (G6PD) deficiency [12-14].

Additional candidate genes associated with subphenotypes of SCD have been described [15]. Clinical manifestations of SCD are generally not apparent until the switch from $\mathrm{HbF}$ to $\mathrm{HbS}$ occurs after the 3rd month of life [15]. This beneficial effect of $\mathrm{HbF}$ has been noted in patients who are compound heterozygotes for $\mathrm{HbS}$ and for hereditary persistence of fetal hemoglobin, or for other genetic variants of SCA with elevated HbF levels. Fetal hemoglobin genes regulation impacts the level of $\mathrm{HbF}$ and its distribution among sickle erythrocytes is highly variable [16, 17]. Little is known on genetic modifiers of SCD severity in Mayotte [18]. This article aims to describe the genetic modulators of SCD in a cohort of pediatric patients followed up in Mayotte between 2007 and 2017.

\section{Methods \\ Study location}

Mayotte is a French territory in the southern hemisphere, between the African continent and Madagascar and in the middle of the Indian Ocean. Its proximity to the Comoros, less than $70 \mathrm{~km}$ away, allows a massive immigration from the other islands of the archipelago to that country [19]. The available care consists of a hospital center located in Mamoudzou, the capital of the territory, 4 referral centers and 13 dispensaries (Fig. 1). Altogether these facilities provide 0.8 beds per 1000 inhabitants (2.1 in mainland France). The medical density is 41 per 100,000 inhabitants (156 in mainland France). For pediatrics, medical density is 10 per 100,000 in Mayotte, versus 64 in mainland France. With an incidence of $1 / 633, \mathrm{SCD}$ is a major public health problem in Mayotte, and because of its social ramifications, it is also a significant social problem in this French overseas territory.

\section{Study design}

This retrospective cohort study was performed using data collected from the medicalized information system program (MISP) of the Center for SCD of the Mamouzou General Hospital in Mayotte. The clinical and biological data collected for this project followed the recommended standard of care of SCD, by the French authority (Haute Autorité de Santé).

\section{Patients}

Patients with SCA or S/beta-thalassemia, younger than 18 years in 2017, were seen every 3 months (with a 


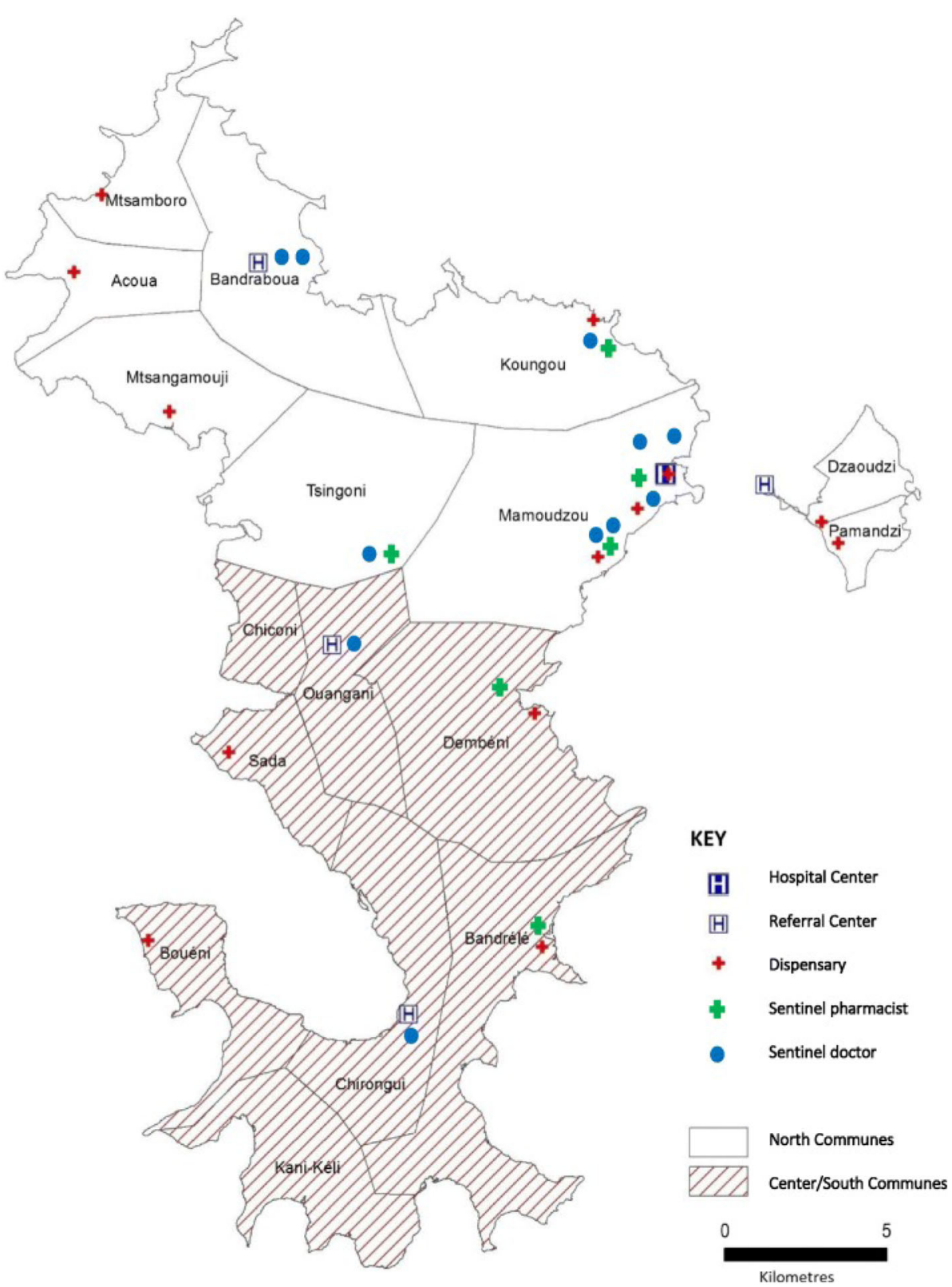

Fig. 1 Map of the Mayotte Hospital Center health centers, 2016-2017 [Source: GeoflalGN, Produced by CIRE OI, 2017]. Map of the communes affected by the water restrictions (center/south and north), the Mayotte Hospital Center health centers, the sentinel pharmacists and doctors, 2016-2017 [Source: GeoflalGN, Produced by CIRE OI, 2017]

consultation by a pediatrician specialized in SCD and a standard biological assessment). A specific appointment was scheduled for annual review (during which the TCDwas carried out). These patients were prospectively included in the database between 2007 and 2017, after obtaining a statement of patient's non opposition, as required by French regulations. For 50\% of them, SCD has been diagnosed by universal neonatal screening [15]. The other $50 \%$, born outside France, were diagnosed late in the presence of VOC or other complications of SCD.

\section{SCD clinical history}

Clinical and biological data, collected between Januar$y 1^{\text {st }} 2007$ and December $31^{\text {st }} 2017$, were considered for the analysis. The patients were in a stable state when these biological data were taken. For each patient, the following data were collected: age, gender, hemoglobin type, alpha and beta globin genotype, beta globin haplotype, basal $\mathrm{HbF}$ level, basal $\mathrm{Hb}$ level, glucose-6phosphate-dehydrogenase (G6PD) status, UGT1A1 gene mutations status, single nucleotide polymorphism (SNP). SNP was genotyped using Single-Tube Fluorescent 
Bidirectional polymerase chain reaction (PCR). The other variables included severity and number of prior acute or chronic sickle cell specific complications (acute splenic or hepatic sequestration, acute chest syndrome, sickling related painful vasoocclusive crisis (VOC), neurologic events, severe infections, acute anemia, cholelithiasis), use of opioids for painful events, hydroxyurea treatment, number of RBCs transfusions (or RBCs exchange), and number of hospitalizations. These data, from the computerized medical record, were transferred in 2017 to an anonymized database for analysis.

\section{Definitions}

The VOC is apainful complication of SCD [20]. We only collected painful events that required hospital treatment. Hemolytic crisis: decreases in the concentration of hemoglobin $(\mathrm{Hb})$ and hematocrit [21]. Hand-foot syndrome: swelling in the hands and feet with pain and/or local heat, which may also be associated with a decrease in $\mathrm{Hb}$ concentration [22]. Infection: fever accompanied by prostration and leukocytosis, with or without other laboratory tests and imaging [21]. Acute splenic sequestration was defined as a sudden increase in the spleen size associated with pain in the left upper quadrant, a decrease in the hemoglobin concentration of at least $2 \mathrm{~g} /$ $\mathrm{dL}$ and in thrombocytes number [22]. Acute hepatic sequestration was defined as a sudden increase in liver size associated with pain in the right upper quadrant, a decrease in the hemoglobin concentration of at least $2 \mathrm{~g} /$ $\mathrm{dL}$, and more abnormal results of liver-function tests not due to biliary tract disease [23]. Acute chest syndrome (ACS) and painful vasoocclusive crisis were defined as previously published [24]. The cerebral vasculopathy results in stroke and subclinical or paucisymptomatic ischemic lesions. It was detected using TCD ultrasonography and magnetic resonance imaging (MRI) $[25,26]$.

\section{Exclusion criteria}

Were excluded from this study infants under 1 year of age on December31 ${ }^{\text {st }} 2017$, because of their high HbF level. Children lost tofollow-up for more than 3 years were also excluded.

\section{Statistical analysis}

The database was anonymised before analysis. The Statistical Package for the Social Sciences (SPSS) statistical software, version 13.0 (SPSS, Chicago, IL) was used for statistical analysis. The data were described as number and percentages for categorical variables and mean \pm standard deviation (SD) or median (range) for continuous variables. Independent Student'st- test was used to compare continuous variables between groups (KruskalWallis test for comparing more than 2 groups), andchi- square test (or Fisher exact test) for categorical data. Multivariable logistic regression was used to examine the association between each of the variables and the sickle subphenotype with adjustment for age and sex. $P$ values $<0.05$ were considered statistically significant. All acute clinical events, correctlyrecorded in the medical files from birth (or the beginning of follow-up) to the date of the final evaluation were included in the analyses. Kaplan-Meyer curves and log-rank test were performed for generating survey curves. We performed a ROC curve for $\mathrm{HbF}$, which allows to distinguish two groups $(\mathrm{HbF}<10 \%$ versus $\mathrm{HbF}>10 \%)$.

\section{Regulatory and ethical authorizations}

All patients or legal representatives (for the children included in the study) gavewritten informed consent to participate in this research. The study cohort was approved by the Mamoudzou Hospital Ethical committeeand the database was declared at the Commission NationaleInformatiqueetLibertés (CNIL $\mathrm{N}^{\circ}$ 2,004,05411/26/2016).

\section{Results}

Ten percent of patients from the Center were lost to follow up (Fig. 2). One hundred and eighty five children were enrolled in this study, $72 \%$ with SCA, $16 \%$ with $\mathrm{Hb} / \mathrm{S} \beta^{0}$-thalassemia and $12 \%$ with $\mathrm{Hb} / \mathrm{S} \beta+$ thalassemia. The mean age was 9.5 years, with ranges from 19 months to 18 years. $15.3 \%$ of the children met the definition criteria of cerebral vasculopathy. There were missing data for 22 of included patients.

\section{Sickle cell genotypes}

In our study, homozygous sickle cell patients had significantly lower mean hemoglobin and hematocrit levels than $S \beta 0$ and then $S \beta+$ patients. On the clinical level, SCA was significantly associated with ACS, bacterial infections, cholelithiasis, hospitalizations and more frequent transfusions (Table 1).

\section{Sickle cell haplotypes}

Having at least one Bantu allele concerned almost all of our study population. The patients with Bantu / Bantu haplotype had significantly lower hematocrit, higher $\mathrm{MCV}$ and MCHC. They were hospitalized andtransfusedmore often (Table 2).

\section{Alpha thalessemia}

Fifty percent of the patients had a alpha-3.7 mutation of at least one alpha gene. The absence of this alphathalassemic mutation was significantly associated with cerebral vasculopathy and more frequent RBC transfusions (Table 3). 


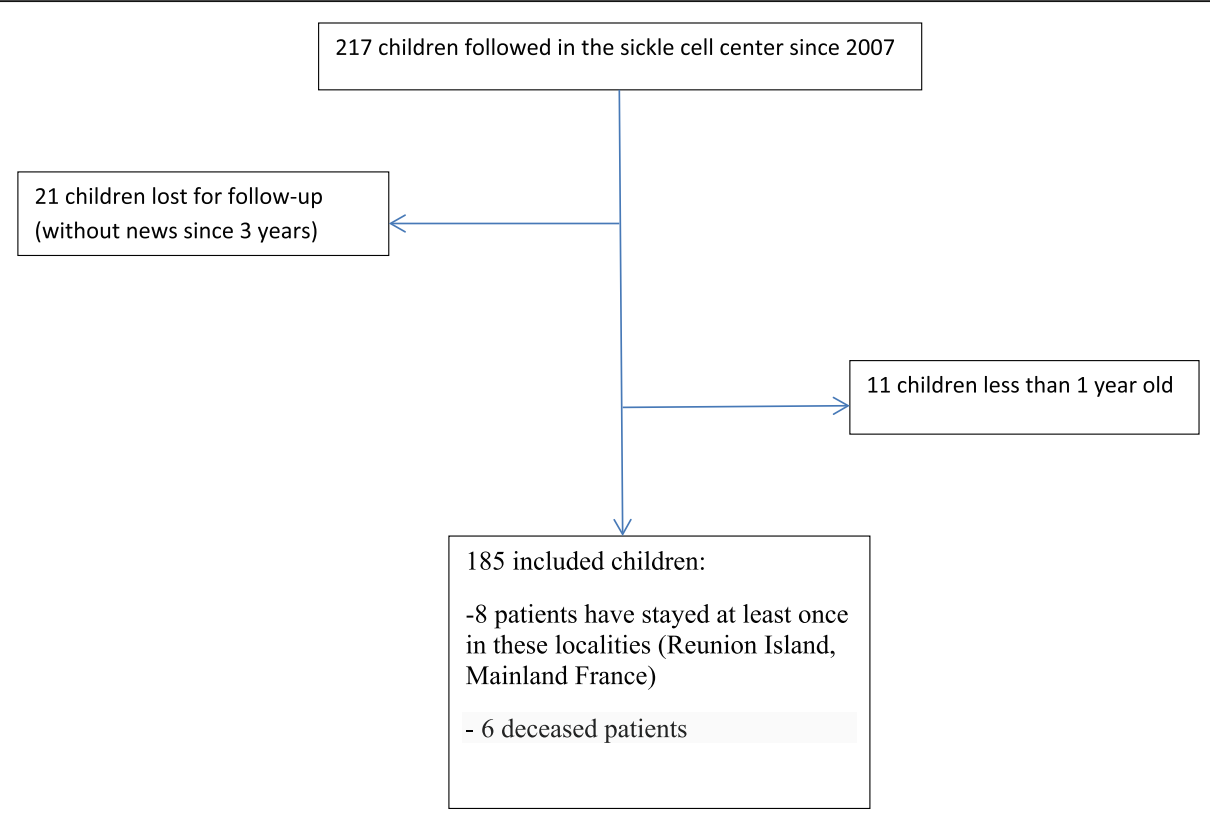

Fig. 2 Flow chart describing how the cohort was identified

Table 1 Comparison of patients characteristics according to the sickle genotypes

\begin{tabular}{|c|c|c|c|c|}
\hline & SS $(n=118)$ & $\operatorname{Sbeta}^{\circ}(n=26)$ & Sbeta $^{+}(n=19)$ & $P$ \\
\hline & \multicolumn{4}{|c|}{ Mean $( \pm$ SD) or $\mathrm{n}(\%)$} \\
\hline $\mathrm{Hb}(\mathrm{g} / \mathrm{dL})$ & $7,8( \pm 0,1)$ & $8,3( \pm 0,3)$ & $8,8( \pm 0,1)$ & \\
\hline Hematocrit (\%) & $24,1( \pm 0,3)$ & $27,0( \pm 0,7)$ & $28,3( \pm 1,0)$ & \\
\hline$M C V(f L)$ & $80,3( \pm 0,9)$ & $65,8( \pm 1,3)$ & $69,3( \pm 2,2)$ & \\
\hline $\mathrm{MCHC}(\mathrm{g} / \mathrm{dL})$ & $32,7( \pm 0,1)$ & $31,0( \pm 0,3)$ & $31,7( \pm 0,3)$ & \\
\hline Reticulocytes (G/L) & $268,1( \pm 9,8)$ & $250,0( \pm 20,9)$ & $179,1( \pm 19,0)$ & 0,003 \\
\hline Leukocytes (G/L) & $13,2( \pm 0,4)$ & $10,6( \pm 0,7)$ & $11,0( \pm 0,7)$ & 0,007 \\
\hline Hospitalization/year & & & & 0,003 \\
\hline No & $13(11,1)$ & $8(32)$ & $7(38,9)$ & \\
\hline 1 to 2 & $91(77,8)$ & $17(68)$ & $11(61,1)$ & \\
\hline$\geq 3$ & $13(11,1)$ & 0 & 0 & \\
\hline Red Blood Cell Transfusion érythrocytaire & & & & 0,001 \\
\hline Never & $20(17,1)$ & $13(52)$ & $8(42,1)$ & \\
\hline Occasionnally & $78(66,7)$ & $11(44)$ & $11(57,9)$ & \\
\hline Transfusion therapy & $19(16,2)$ & $1(4)$ & 0 & \\
\hline Infection & $61(55)$ & $8(30,8)$ & $6(31,6)$ & 0,026 \\
\hline Acute Chest Syndrome & $27(23,9)$ & 0 & $4(21,1)$ & 0,009 \\
\hline Number of ACS/year & & & & 0,041 \\
\hline Never & $80(74,1)$ & $25(100)$ & $15(78,9)$ & \\
\hline 1 & $22(20,4)$ & 0 & $3(15,8)$ & \\
\hline$\geq 2$ & $6(5,5)$ & 0 & $1(5,3)$ & \\
\hline Cholelithiasis & $28(26,4)$ & $4(18,2)$ & 0 & 0,038 \\
\hline
\end{tabular}




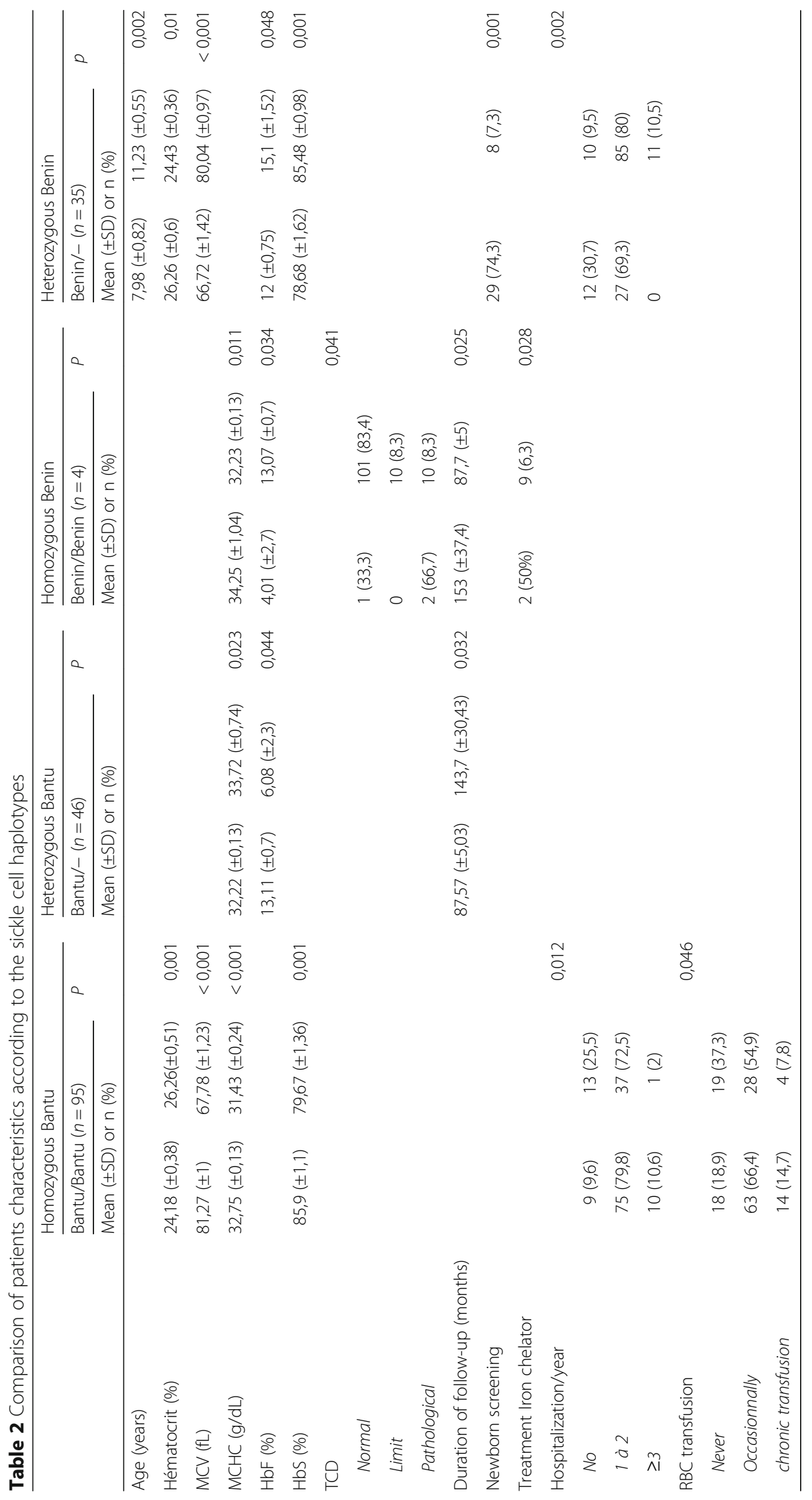


Table 3 Comparison of patients characteristics according to the alpha thalassemia trait

\begin{tabular}{|c|c|c|c|}
\hline & Alpha thalassemia trait $(n=80)$ & No alpha thalassemia trait $(n=52)$ & $P$ \\
\hline & Mean $( \pm$ SD) or $n(\%)$ & & \\
\hline $\mathrm{Hb}(\mathrm{g} / \mathrm{d} \mathrm{L})$ & $8,2( \pm 0,1)$ & $7,7( \pm 0,2)$ & 0,007 \\
\hline Hématocrit (\%) & $25,6( \pm 0,4)$ & $23,8( \pm 0,5)$ & 0,004 \\
\hline MCV (fL) & $73,3( \pm 1)$ & $81,8( \pm 1,5)$ & $<0,001$ \\
\hline Reticulocytes (G/L) & $239,6( \pm 10)$ & $288,2( \pm 13,8)$ & 0,004 \\
\hline TCD & & & 0,017 \\
\hline Normal & $72(90)$ & $37(71,2)$ & \\
\hline Limit & $3(3,7)$ & $8(15,4)$ & \\
\hline Pathological & $5(6,3)$ & $7(13,4)$ & \\
\hline Splenomegaly ratio & $0,54( \pm 0,03)$ & $0,43( \pm 0,05)$ & 0,057 \\
\hline Cerebral vasculopathy & & & 0,004 \\
\hline Yes & $78(91,8)$ & $43(72,9)$ & \\
\hline Pathological TCD/MRI & $7(8,2)$ & $13(22)$ & \\
\hline Stroke & 0 & $3(5,1)$ & \\
\hline RBC Transfusion & & & 0,028 \\
\hline No & $28(29,4)$ & $10(15,6)$ & \\
\hline Occasionnally & $60(63,2)$ & $42(65,6)$ & \\
\hline Exchange transfusion & $7(7,4)$ & $12(18,8)$ & \\
\hline
\end{tabular}

\section{Single nucleotide polymorphism}

Table 4 shows the different SNP associated with the hemolytic subphenotype. The table of patient characteristics according to the SNP, being very complex given the large number of variables, we found it simpler here to describe the data. The presence of Xmn1 in our cohort was significantly associated with higher hemoglobin and hematocrit levels, decreased leukocytes, and a higher splenic ratio. Having two favourable SNP alleles rs4671393 was significantly associated with higher hemoglobin and hematocrit, and a higher $\mathrm{HbF}$ for patients under HU treatment, as well as lower HbS. Patients with at least one favourable rs11886868 allele had higher hemoglobin and hematocrit. Patients with at least one favorable rs1427407or rs9399137 alleles had higher HbFlevel. The favourable rs10189857 allele was associated with a low hemoglobin and hematocrit and high leucocytes. Patients with the favourable rs28384513 allele were more frequently diagnosed with the neonatal screening test. The absence of TAC deletion at SNP rs66650371 was significantly associated with higher mortality.

\section{UGT1A1 gene mutations status}

The low number of patients with the UGTA1 mutation $(n=23,12 \%)$ did not allow statistical analysis.

\section{Hemoglobin F (Table 5)}

The survival analysis without occurrence of cerebral vasculopathy showed that the group of patients with $\mathrm{HbF}>$ $10 \%$ presented a significantly greater risk of early onset of cerebral vasculopathy, the main complication of the hemolytic sub-phenotype (Fig. 3). The group with low $\mathrm{HbF}$ was associated with vaso-occlusive complications.

Table 4 SNP associated with the hemolytic subphenotype

\begin{tabular}{|c|c|c|c|c|}
\hline SNP & Avantageous allele/Disadvantageous allele & Allele frequency (\%) & OR $(95 \% \mathrm{Cl})$ & $P$ \\
\hline BCL11A rs4671393 & $A / G$ & $37 \%$ & $3,13[1,1-8,89]$ & 0,047 \\
\hline BCL11A rs11886868 & $\mathrm{C} / \mathrm{T}$ & $43 \%$ & $4,28[1,6-11,5]$ & 0,005 \\
\hline BCL11A rs1427407 & $T / G$ & $15 \%$ & $4,02[1,75-9,22]$ & 0,001 \\
\hline HMIP rs9399137 & $\mathrm{C} / \mathrm{T}$ & $7 \%$ & $5,92[1,28-27,4]$ & 0,012 \\
\hline Xmn1 rs7842144 & $\mathrm{T} / \mathrm{C}$ & $6 \%$ & - & 0,76 \\
\hline BCL11A rs10189857 & A/G & $54 \%$ & - & 0,85 \\
\hline HMIP rs28384513 & $\mathrm{C} / \mathrm{A}$ & $67 \%$ & - & 1 \\
\hline HMIP rs66650371 & Deletion/ACT & $37 \%$ & - & 0,39 \\
\hline
\end{tabular}


Table 5 Characteristics of the patients followed in Mayotte according to the HbF level

\begin{tabular}{|c|c|c|c|c|c|}
\hline Profile & $\mathrm{HbF} \geq 10 \%$ & $\mathrm{HbF}<10 \%$ & OR $(95 \% \mathrm{Cl})$ & $P$ & $P^{*}$ \\
\hline Age, Mean (SD) & $8,6( \pm 0,5)$ & $12,1( \pm 0,6)$ & & $<0,001$ & 0.09 \\
\hline Hemoglobin sickle cell genotype $\mathrm{n}(\%)$ & & & & 0.187 & 0.2 \\
\hline HbSS & $58(68,2)$ & $60(76,9)$ & & & \\
\hline HbS $/ \beta^{\circ}$ Thalassemia & $18(21,2)$ & $8(10,3)$ & & & \\
\hline $\mathrm{HbS} / \beta^{+}$Thalassemia & $9(10,5)$ & $10(12,8)$ & & & \\
\hline \multicolumn{6}{|l|}{ Haplotypes n (\%) } \\
\hline Bantu/- & $79(97,5)$ & $62(93,9)$ & & 0.41 & 0.45 \\
\hline Bantu/Bantu & $48(59,3)$ & $47(71,2)$ & & 0.14 & 0.18 \\
\hline Benin/- & $27(69,2)$ & $12(18,2)$ & $2,25[1,03-4,9]$ & 0.04 & 0.4 \\
\hline Benin/Benin & $1(1,2)$ & $3(4,5)$ & & 0.33 & 0.5 \\
\hline Alpha thalassemia n(\%) & $56(60,2)$ & $42(58,3)$ & & 0.87 & 0.8 \\
\hline \multicolumn{6}{|l|}{ G6PD deficiency n(\%) } \\
\hline G6PD-Deficiency & $5(6,4)$ & $7(10,3)$ & & 0.02 & 0.2 \\
\hline Heterozygote & $4(5,1)$ & $12(17,6)$ & & & \\
\hline UGT1A1 mutation n (\%) & $12(14)$ & $11(15,1)$ & & 1 & 1 \\
\hline \multicolumn{6}{|l|}{ SNP n (\%) } \\
\hline BCL11A or rs 4671393 & $20(19,8)$ & $7(8)$ & $3,13[1,1-8,89\}$ & 0.047 & 0.2 \\
\hline BCL11A rs 11886868 & $28(63,6)$ & $9(29)$ & $4,28[1,6-11,5]$ & 0.005 & 0.06 \\
\hline BCL11A rs 1427407 & $28(41,8)$ & $10(15,2)$ & $4[1,75-9,22]$ & 0.001 & 0.051 \\
\hline HMIP rs9399137 & $12(14,3)$ & $2(2,7)$ & $5,92[1,28-27,4]$ & 0.01 & 0.24 \\
\hline Xmn1 or rs 7842144 & $6(7,2)$ & $4(5,7)$ & & 0.76 & 0.74 \\
\hline BCL11A rs 10189857 & $64(79)$ & $55(77,5)$ & & 0.85 & 0.8 \\
\hline HMIP rs28384513 & $30(73,2)$ & $23(74,2)$ & & 1 & 1 \\
\hline HMIP rs66650371 & $31(41,3)$ & $22(33,3)$ & & 0.39 & 0.4 \\
\hline HMIP rs4895441 & $7(17,1)$ & $2(6,5)$ & & 0.28 & 0.3 \\
\hline Hydroxyurea treatment & $11(11)$ & $19(22,1)$ & & 0.047 & 0.5 \\
\hline Osteonecrosis (n, \%) & $1(1,3)$ & $8(11,1)$ & & & \\
\hline Number of hospitalization (n, \%) & & & & 0.01 & 0.1 \\
\hline No & $21(21)$ & $14(16,5)$ & & & \\
\hline 1 à 2 per year & $77(77)$ & $60(70,6)$ & & & \\
\hline$\geq 3$ per year & $2(2)$ & $11(12,9)$ & & & \\
\hline
\end{tabular}

$p^{*}$ obtained after a multivariate analysis

Homozygous Bantu patients in the HbF group $>10 \%$ were was associated with an increase in hemoglobin level in less hospitalized $(p=0.002)$, less transfused $(p=$ $0.025)$, had less VOC / year $(p=0.039)$, but they had more cerebral vasculopathy $(p=0.023)$ than those with $<10 \% \mathrm{HbF}$. Homozygous Bantu patients in the $\mathrm{HbF}$ group $<10 \%$ had less cholelithiasis $(p=0.021)$. Patients in both groups, when they carried one or two Benin haplotypes, were less hospitalized $(p=0.002)$, had less VOC per year $(p=0.039)$ and their 1 st VOC occurred less early $(p=0.03)$ than those that did not have any Benin haplotypes. Only the patients heterozygous for Benin haplotypes had a significant high HbF level $(p=0.04)$. Patients who do not carry a Benin allele were more transfused $(p=0.018)$ than those who did. The alphathalassemic mutation was associated with an increase in hemoglobin level in patients at risk of vasculopathy ( $p=$ $0.023)$, and an increased leukocyte rate $(p=0.001)$. Children in the group with an alpha mutation were hospitalized less often $(p=0.004)$ and were less likely to have cholelithiasis $(p=0.041)$ than other children. Children in the $<10 \% \mathrm{HbF}$ group who carried an alpha mutation received fewer transfusions than those $>10 \%(p=$ 0.048). Multivariate analysis (Table 5) did not find any independent genotypic marker. However, some SNPs were close to significance: BCL11A rs1427407 $(p=$ $0.051)$ and BCL11A rs11886868 $(p=0.06)$. BCL11A rs4671393 $(p=0.2)$ and HMIP rs9399137 $(p=0.24)$ were 


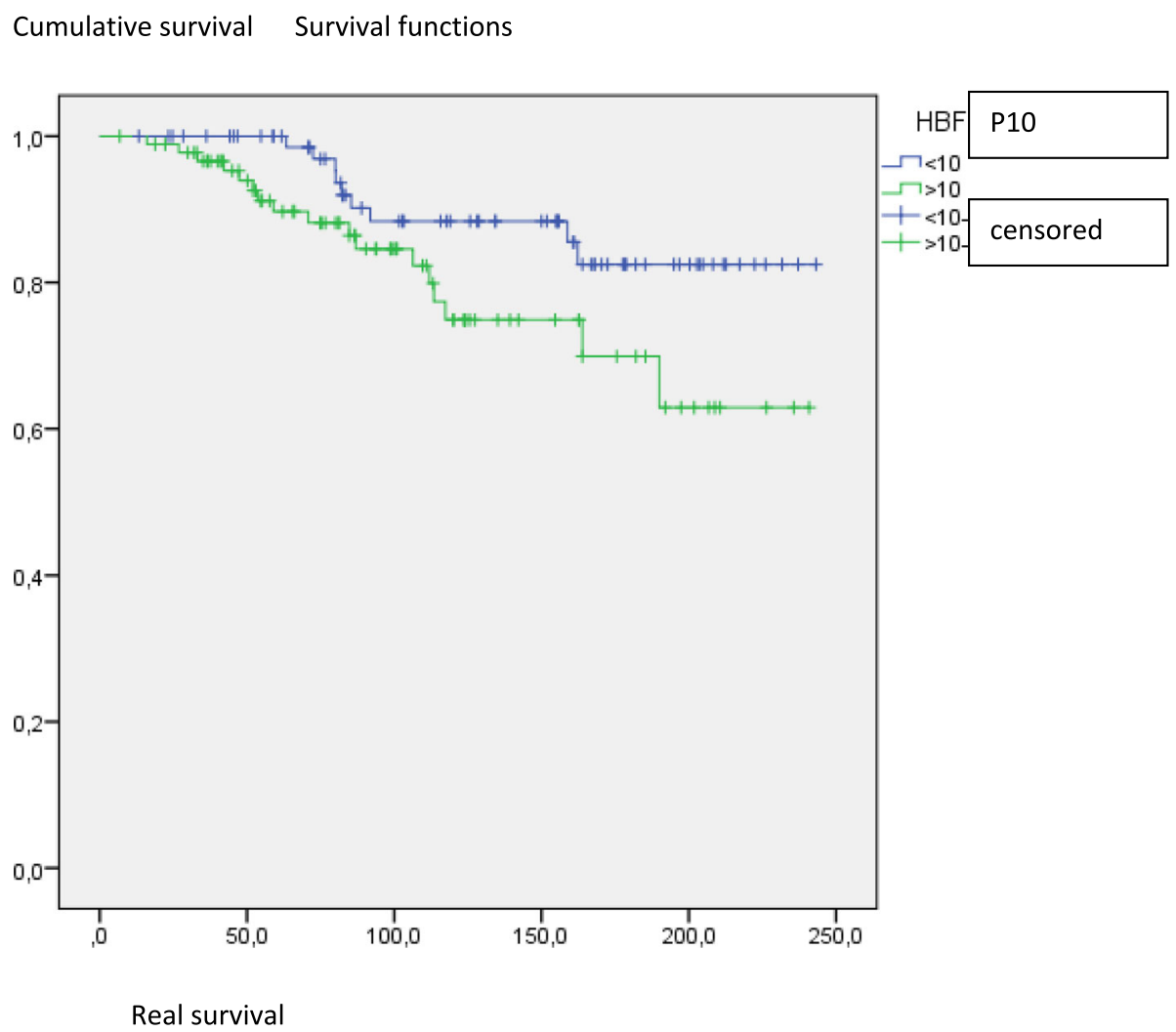

Fig. 3 Survival without cerebral vasculopathy according to the Hb F level

not independently associated with the phenotypic groups. A concordance chi-2 test found preferential associations between some SNPs (Table 6). The linkage imbalance between BCL11A rs66650371 and rs9399137 was highly significant for a large number.

\section{G6PD deficiency}

Patients with G6PD mutation had a greater MCV $(p=$ $0.05)$, and more infections $(p=0.045)$ than those without. Regarding patient management, TCD was performed more often $(p=0.026)$, iron chelatorsand transfusion were prescribed more often $(p=0.001$ and $p=0.045$, respectively).

\section{Discussion}

According to our working hypothesis, the HbF level could direct us towards a sub-phenotype of the disease.

Table 6 Linkage imbalances between SNPs according to the number of studied samples

\begin{tabular}{llll}
\hline Locus & Single nucleotide polymorphism & $N$ & Concordance $(p)$ \\
\hline BCL11A & rs11886868-rs1427407 & 54 & $<0.001$ \\
& rs1427407-rs4671319 & 51 & $<0.001$ \\
HMIP & rs9399137-rs4895441 & 72 & $<0.001$ \\
& rs66650371-rs9399137 & 141 & $<0.001$ \\
\hline
\end{tabular}

We therefore looked for a $\mathrm{HbF}$ value to determine these two sub-phenotypes. Our study population was characterized by the predominance of sickle cell anemia, with a severe clinical presentation [27], followed by the compound heterozygous $\mathrm{HbS} / \beta$ thalassemia. The Bantu haplotype, accounting for $80 \%$ of the alleles, reflects the East African origin of the Mahoran population [28]. Compared to the previous study conducted in Mayotte, haplotypes seemed to diversify: $64.9 \%$ of homozygous Bantou in 2017, against 88\% in 2011 [18]. The Benin, Cameroon and Senegal haplotypes appeared or became more frequent in the past 6 years. Intense immigration to Mayotte could partly explain this result. But, this should be taken with caution even if the inclusion criteria were not the same, the previous study only considering children who had been diagnosed by the neonatal screening. The Bantu haplotype was not directly related to a particular phenotypic group, but increased the risk of cerebral vasculopathy in patients with $\mathrm{HbF}>10 \%$. It was probably difficult to highlight a statistical link because of its very high frequency in our population. The Bantu haplotype is classically associated with a more severe prognosis, and appears to be related to greater hemolysis in a study comparing Jamaican and Ugandan populations, and in another involving a Brazilian cohort $[29,30]$. The Benin haplotype was associated with the 
vasooclusive phenotype in our study. It corresponded to more severe phenotypes than other haplotypes (Senegal, Arabo-Indian), but is not known to be associated with the risk of cerebral vasculopathy. The G6PD mutation was associated with more transfusions because of lower $\mathrm{Hb}$ levels. This link was not found at the level of phenotypic groups. The studies on this subject obtained different results: G6PD deficiency leads to a hemolytic phenotype according to some French studies [31, 32], and does not affect this phenotype according to others [33-37]. Our study investigated three mutations, but did not collect the molecular and clinical expression of G6PD deficiency. It didnot take into account the possible presence of other mutations, and possible chromosomal inactivation by lyonization. It would be interesting to specifythe residual enzymatic activity and the clinical complications presented by the patients.

\section{$\mathrm{HbF}$ is associated with a high risk of cerebral vasculopathy}

Our survival analysis without occurrence of cerebral vasculopathy showed that the group of patients with $\mathrm{HbF}>$ $10 \%$ presented a significant risk of early onset of cerebral vasculopathy. Even if predicting sickle cell severity is complex, stroke appears to be the most devastating complication of sickle cell anemia (SCA), affecting up to $30 \%$ of children with the disease. Despite the relative frequency of stroke in SCA, few predictors of this risk have been described [38-40]. Thus our severity classification based on the "existence or not of the risk of cerebral vasculopathy" enabled us to better characterize the role of genetic modifiers of SCA. By inhibiting $\mathrm{HbS}$ polymerization and reducing the tissue injury, $\mathrm{HbF}$ is the predominant modulator of the phenotype of sickle cell anemia [40]. Our patients with high hemoglobin F had less VOC, and were hospitalizedless often. Because of their less preoccupying symptomatology, they were less often seen in the follow-up consultation. As a result, they were at greater risk of developing silent cerebral vasculopathy, with diagnostic delays since they did not benefit from regular DTC. On the contrary, low $\mathrm{HbF}$ was associated with vaso-occlusive complications, requiring treatment with hydroxycarbamide (HU). However hydroxycarbamide is the only $\mathrm{HbF}$ inducer approved for the treatment of SCD [39]. As reported in several studies, HbF levels have a clinically beneficial effect on SCD [40]. Bantu and Benin haplotypes also express relatively lower $\mathrm{Hb} F$ levels, with a severe clinical presentation. Indeed, among the predictors of survival, $\mathrm{HbF}$ levels play a significant role in lowering the morbidity and mortality. Co-inheritance of $\mathrm{HbS}$ and hereditary persistence of fetal hemoglobin (HPFH) may contribute to variable $\mathrm{HbF}$ levels in SCD patients, thus influencing their clinicopathological profile [40]. In fact, in patients with $\mathrm{HbF}>10 \%$, there were observed a residual risk of vasculopathy when risk of VOC disappears. It is known that in SCD patient recurrent stroke persists until $\mathrm{HbS}$ decreases to $30 \%$, needing high level of $\mathrm{HbF}$ in patients without blood transfusion [41]. HbF inhibits $\mathrm{HbS}$ polymerization and its abundance in the red blood cells dilutes down the concentration of HbS. In 2012, Steinberg et al. synthesized the results of studies on the association between $\mathrm{HbF}$ and sickle cell clinical phenotype. They found no or little evidence of a protective effect of $\mathrm{HbF}$ on cerebral vasculopathy, pulmonary arterial hypertension, priapism and glomerulopathy [15]. Indeed, $\alpha$ thalassemia has been shown to diminish the severity of disease by reducing the amount of sickled RBC, decreasing the intracellular $\mathrm{HbS}$ level, and also increasing $\mathrm{HbF}$ level. Our study showed a high prevalence of $3.7 \mathrm{~kb} \alpha-$ globin gene deletion. This has also been reported among SCA patients in Tanzania [42], in Guadeloupe [43], in Brazil [44], in India [45], in Saudi Arabia [46], in France among Africans [7], and in Cameroon [47]. The beneficial effect of $\mathrm{HbF}$ is explained by its ability to prevent sickling. However, the intra-erythrocyte distribution of $\mathrm{HbF}$ is heterogeneous. Also, BCL11A and HBS1L-MYB SNPs in the $\beta$-globin gene have been found to be associated witha high level of $\mathrm{HbF}$, usually under conditions of poor erythropoiesis, such as SCD [7].

\section{Correlation of genotype to subphenotypes SNPs associated with high $\mathrm{Hb}$ F level}

Investigation of genetic variants has identified several genes as principal influencers of $\mathrm{HbF}$ regulation. In our study, the alleles BCL11A rs1427407, HMIP rs4895441 and HMIP rs9399137 were significantly associated with an increase in HbF. In the literature, these SNPs are indeed strongly associated with HbF. BCL11A rs1427407 was the SNP with the highest correlation withHbF in a Genome wide association study (GWAS) performed in Tanzania [48]. SNPs BCL11A rs4671393, BCL11A rs11886868, and HMIP rs4895441 increase the induction of $\mathrm{HbF}$ with hydroxycarbamide. This effect was found in several cohorts (North America, Brazil), where BCL11A was most strongly associated with an increase in $\mathrm{HbF}$ under hydroxycarbamide, regardless of its effect on basal $\mathrm{HbF}[7,49]$. The mechanism of action is not explained. The association of SNPs with HbF varies between populations of different origins, so some SNPs have no effect in some populations. This was the case forXmn1 in our cohort, which may have resulted from its rarity. A study comparing two cohorts of European and African origin observed differences in allele frequency and correlation with $\mathrm{HbF}$ [50]. Another study, conducted in Cameroon, showed identic allelic frequencies between a Cameroonian population and the African-American cohort, but a lower impact on $\mathrm{HbF}$ among Africans [51]. These results 
show the interest of looking for SNPs in a given population by performing GWAS, and not simply extrapolating the polymorphisms found in another population. The African continent in particular could benefit from more GWAS polymorphisms Xmn1. BCL11A rs4671393 and BCL11A rs11886868 are associated with elevated hemoglobin. This result is found in other African studies $[48,52]$. HMIP rs66650371 is correlated with a decrease in mortality on a small population in our cohort, which is not reported (to our knowledge) in the literature.

The most remarkable result of our study was the association of SNPs with the phenotypic groups that we aimed to determine. BCL11A rs4671393, BCL11A rs11886868, BCL11A rs1427407 and HMIP rs9399137 were correlated with the $\mathrm{HbF}$ group $>10 \%$, which presents a higher risk of cerebral vasculopathy and would be oriented towards the hemolytic sub-phenotype. BCL11A rs1427407 was the most strongly associated in our population, which corresponds to its strong correlation with $\mathrm{HbF}$ found in the Tanzanian GWAS [48]. HMIP rs9399137 is the HMIP polymorphism most strongly associated with $\mathrm{HbF}$ levels in African populations [53]. Multivariate analysis found no independent association of these SNPs with clinical profiles, BCL11A rs1427407 being close to significance. There are therefore unknown factors (interactions, intermediate factors, or other SNPs in linkage disequilibrium) that intervene in this genotype-phenotype correlation HMIP rs66650371 was not associated with either $\mathrm{HbF}$ or a phenotypic group in our cohort. This deletion of 3 bases, in linkage disequilibrium with rs9399137 in the literature as in our study, is located at the binding sites of four essential transcription factors in erythroid differentiation. It inhibits the expression of MYB, and thus leads to both an acceleration of differentiation (responsible for an increase in $\mathrm{HbF}$ ) and a decrease in erythrocyte proliferation (which could cause a decrease in hemoglobin) $[7,53,54]$. These two effects could explain the lack of correlation with the clinical phenotype. The favorable SNP rs66650371 is less common in African populations and particularly in our cohort, which may also explain the lack of observed link. We also did not find any clinical phenotypic association for the SNP Xmn1, which is also infrequent in our population. This geno-phenotypic clinical association in sickle cell disease is interesting because it is poorly described in the literature. In 2008, Lettre found a significant link between the association of 5 SNPs (BCL11A rs4671393, HMIP rs28384513, rs9399137 and rs4895441, and XmnI rs7482144) and the reduction of VOCs in the SCD cohort [55]. These SNPs are also associated with a less severe clinical phenotype in another pathology of hemoglobin, beta-thalassemia [56]. The results of Lettre and other studies show a stronger geno-phenotypic correlation when several SNPs are associated [55, 57]. It would therefore be interesting to study the link between these sets of specific polymorphisms and the sub-phenotypes of sickle cell disease. Our study found an association between some SNPs and the risk of cerebral vasculopathy; this link depends on the frequency of the polymorphism, the correlation rate according to the population, and could be amplified by the association of these SNPs.

The alpha-thalassemic mutation is a vaso-occlusive profile The alpha-thalassemic mutation was associated with a decrease of hemolysis biological parameters (anemia, reticulocytes), and less cerebral vasculopathy. In the literature, it is also associated with fewer vascular complications $[15,58$, 59]. This mutation decreases the parameters and complications of hemolysis in the at-risk group of vasculopathy. It protects against vascular complications, even in patients who are at high risk. This is due to the decrease in $\mathrm{HbS}$ concentration in erythrocytes, which leads to a decrease in hemolysis $[31,60]$. The resulting increase in blood viscosity favors vaso-occlusive complications [60].

\section{Limitations and interests of our study}

Our determination of the sickle cell sub-phenotypes from the HbF level didnot yield the expected result, although some trends have emerged. Difficulties in monitoring the Mahoran pediatric patients lead to poor control of environmental prognostic factors such as lifestyle, therapeutic education of the patient, screening and early management, and regular monitoring. This may have impacted some results of our study. However, we relied on the fact that environmental factors do not appear to affect the type of expression of the disease [18]. The number of missing data, which is too high for some parameters, requires further study. The analyzed SNPs were not, for some, the most frequent or the most strongly associated with the $\mathrm{HbF}$ level in an African population. GWAS and genotype-phenotype correlation research must be adapted to different types of populations for a better global understanding of SCD. Our results, need to be further developed, could make it possible to predict early (in utero or during the neonatal period) the type of complication that the sickle cell child will present, and thus to predict the type of surveillance and treatment required for each patient. They could help in the decision of intensiveinterventionssuch as bone marrow transplantations.

\section{Conclusion}

Our study allowed a description of the Mahoran pediatric population, reflecting the need to continue to improve monitoring clinical data continuously. In our cohort, the SNPs BCL11A rs4671393, BCL11A rs11886868, BCL11A rs1427407 and HMIP rs9399137 were associated with the group of children with $\mathrm{HbF}>10 \%$, and which seemed to present a high risk 
of occurrence of cerebral vasculopathy. This link was not found independently for each SNP. Beta-globin haplotypes and alpha-thalassemic mutations might also influence the clinical expression of the disease, but the multivariate analysis did not find any independent genotypic marker.

\section{Abbreviations \\ SCD: Sickle cell disease; WBC: White blood cells; RBC: Red blood cells; HbF: Fetal hemoglobin; G6PD: Glucose-6-phosphate-dehydrogenase; UGT1A1: Uridine-diphosphoglucuronate glucuronosyltransferase; VOC: Vasoocclusive crisis; Hb: Hemoglobin; ACS: Acute chest syndrome; SD: Standard deviation; SCA: Sickle cell anemia; MCV: Mean Corpuscular Volume; MCHC: Mean Corpuscular Hemoglobin Concentration; SNP: Single nucleotide polymorphism; HU: Hydroxy-urea; GWAS: Genome wide association study}

\section{Acknowledgements}

The authors would like to thank Pr Mathieu NACHER fromthe INSERM U1424 of Cayenne Hospital, Rue des flamboyants, BP 6006, 97306 Cayenne Cedex, French Guiana, forhisadvice and corrections.

\section{Authors' contributions}

AC and NE drafted the manuscript, TS, MM, JL, LL, JP collectedthedata. AC, SP and JB provided necessary logistic support and formal analysis. AC and NE provided critical comments on the manuscript. All authors have read and approved the manuscript.

\section{Funding}

There is no fund related to this study.

\section{Availability of data and materials}

Our database is available from the corresponding author on reasonable request.

\section{Ethics approval and consent to participate}

An informed written consent to participate in the study has been obtained from participants. The study cohort was approved by the Mamoudzou Hospital Ethical committee and the database was declared at the Commission Nationale Informatique et Libertés (CNIL № 2004054-11/26/ 2016).

\section{Consent for publication}

Not applicable.

\section{Competing interests}

The authors declare that they have no competing interests.

\section{Author details}

'Pediatric Unit, Mamoudzou General Hospital, 1, Rue de I'Hopital, BP 4, 97600 Mamoudzou, Mayotte, France. ${ }^{2}$ APHP, GHU H Mondor, departement de genetique, INSERM-IMRB U955eq2/GREX, 51 Avenue du Maréchal de Lattre de Tassigny, 94010 Créteil Cedex, France. ${ }^{3}$ Pediatric Medicine and Surgery, Cayenne General Hospital, Cayenne, French Guiana, France.

Received: 28 February 2020 Accepted: 1 June 2020

Published online: 20 June 2020

\section{References}

1. Azar S, Wong TE. Sickle cell disease: a brief update. Med Clin North Am. 2017;101(2):375-93.

2. McGann PT, Nero AC, Ware RE. Current management of sickle cell anemia. Cold Spring Harb Perspect Med. 2013;3(8):a011817.

3. Thein SL. Genetic basis and genetic modifiers of $\beta$-thalassemia and sickle celldisease. Adv Exp Med Biol. 2017;1013:27-57.

4. Chang AK, Ginter Summarell CC, Birdie PT, Sheehan VA. Genetic modifiers of severity in sickle cell disease. Clin Hemorheol Microcirc. 2018;68(2-3):147-64.

5. Habara A, Steinberg MH. Minireview: genetic basis of heterogeneity and severity in sickle cell disease. Exp Biol Med (Maywood). 2016;241(7):689-96.
6. Flanagan JM, Frohlich DM, Howard TA, Schultz WH, Driscoll C, Nagasubramanian R, et al. Genetic predictors for stroke in children with sickle cell anemia. Blood. 2011;117:6681-4.

7. Akinsheye I, Alsultan A, Solovieff N, Ngo D, Baldwin CT, Sebastiani P, et al. Fetal hemoglobin in sickle cell anemia. Blood. 2011;118:19-27.

8. Steinberg MH, Embury SH. Alpha-thalassemia in blacks: genetic and clinical aspects and interactions with the sickle hemoglobin gene. Blood. 1986;68: 985-90.

9. Zago MA, Figueiredo MS, Ogo SH. Bantu beta-S cluster haplotype predominates among Brazilian blacks. Am J Phys Anthropol. 1992;88(3):295-

10. Loggetto SR. Sickle cell anemia: clinical diversity and beta S-globin haplotypes. Rev Bras Hematol Hemoter. 2013;35(3):155-7.

11. Belisário AR, Martins ML, Brito AM, Rodrigues CV, Silva CM, Viana MB. BGlobin gene cluster haplotypes in a cohort of 221 children with sickle cell anemia or $\mathrm{S}$ betaO-thalassemia and their association with clinical and hematological features. Acta Haematol. 2010;124(3):162-70 Erratum in: Acta Haematol. 2011;125(3):120

12. Sheehan VA, Luo Z, Flanagan JM, BABY HUG Investigators, et al. Genetic modifiers of sickle cell anemia in the BABY HUG cohort: influence on laboratory and clinical phenotypes. Am J Hematol. 2013;88(7):571-6.

13. Bernaudin F, Arnaud C, Kamdem A, Hau I, Lelong F, Epaud R, et al. Biological impact of a genes, $\beta$ haplotypes, and G6PD activity in sickle cell anemia at baseline and with hydroxyurea. Blood Adv. 2018;2(6):626-37.

14. Steinberg MH, Adewoye AH. Modifier genes and sickle cell anemia. Curr Opin Hematol. 2006;13(3):131-6.

15. Steinberg MH, Sebastiani P. Genetic modifiers of sickle cell disease. Am J Hematol. 2012:87(8):795-803.

16. Ngo DA, Akinsheye I, Hankins JS. Fetal hemoglobin levels and hematologic characteristics of compound heterozygotes for $\mathrm{HbS}$ and deletional hereditary persistence of fetal hemoglobin. Br J Haematol. 2012:156(2):259-64

17. Bhatnagar P, Purvis S, Barron-Casella E, DeBaun MR, Casella JF, Arking DE, et al. Genome-wide association study identifies genetic variants influencing F-cell levels in sickle-cell patients. J Hum Genet. 2011;56:316-23.

18. Muszlak M, Pissard S, Badens C, Chamouine A, Maillard O, Thuret I, et al. Genetic modifiers of sickle cell disease: a genotype-phenotype relationship study in a cohort of 82 children on Mayotte Island. Hemoglobin. 2015:39(3): 156-61.

19. INSEE. Estimation de la population au 1 er janvier 2016. https://www.insee. fr/fr/statistiques/1893198/estim-pop-dep-sexe-1975-2020.xls.

20. Kaul DK, Finnegan E, Barabino GA. Sickle red cell-endothelium interactions. Microcirculation. 2009;16(1):97-111.

21. Rees DC, Williams TN, Gladwin MT. Sickle-cell disease. Lancet. 2010; 376(9757):2018-31.

22. Brousse V, Makani J, Rees DC. Management of sickle cell disease in the community. BMJ. 2014;348:g1765.

23. Shah R, Taborda C, Chawla S. Acute and chronic hepatobiliary manifestations of sickle cell disease: a review. World J Gastrointest Pathophysiol. 2017;8(3):108-16.

24. Vichinsky EP, Styles LA, Colangelo LH, Wright EC, Castro O, Nickerson B. Acute chest syndrome in sickle cell disease: clinical presentation and course. Cooperative study of sickle cell disease. Blood. 1997;89(5):1787-92.

25. Helton KJ, Adams RJ, Kesler KL, Lockhart A, Aygun B, Driscoll C, et al. Magnetic resonance imaging/angiography and transcranial Doppler velocities in sickle cell anemia: results from the SWiTCH trial. Blood. 2014; 124(6):891-8.

26. Bernaudin F, Verlhac S, Arnaud C, Kamdem A, Chevret S, Hau I, et al. Impact of early transcranial Doppler screening and intensive therapy on cerebral vasculopathy outcome in a newborn sickle cell anemia cohort. Blood. 2011; 117(4):1130-40.

27. Aleluia MM, Fonseca TCC, Souza RQ, Neves Fl, da Guarda CC, Santiago RP, et al. Comparative study of sickle cell anemia and hemoglobin SC disease: clinical characterization, laboratory biomarkers and genetic profiles. BMC Hematol. 2017;17:15

28. Sickle-Cell Anemia : A Look At Global Haplotype Distribtion. https://www. nature.com/scitable/topicpage/sickle-cell-anemia-a-look-at-global-8756219/.

29. Ndugwa C, Higgs D, Fisher C, Hambleton I, Mason K, Serjeant BE, et al. Homozygous sickle cell disease in Uganda and Jamaica a comparison of Bantu and Benin haplotypes. West Indian Med J. 2012:61(7):684-91. 
30. Carvalho-dos Santos BS, Dias-Elias DB, da Silva-Rocha LB, Cavalcante-Barbosa M, Pinheiro-Gonçalves R. Impact of $\beta(S)$-globin haplotypes on oxidative stress in patients with sickle cell anemia in steady state. Arch Med Res. 2012; 43(7):536-40.

31. Joly P, Garnier N, Kebaili K, Renoux C, Dony A, Cheikh N, et al. G6PD deficiency and absence of a-thalassemia increase the risk for cerebral vasculopathy in children with sickle cell anemia. Eur J Haematol. 2016;96(4): 404-8.

32. Benkerrou M, Alberti C, Couque N, Haouari Z, Ba A, Missud F, et al. Impact of glucose-6phosphate dehydrogenase deficiency on sickle cell anaemia expression in infancy and early childhood: a prospective study. $\mathrm{Br} J$ Haematol. 2013;163(5):646-54.

33. Diop S, Sene A, Cisse M, Toure AO, Sow O, Thiam D, et al. Prevalence and morbidity of G6PD deficiency in sickle cell disease in the homozygote. Dakar Méd. 2005:50(2):56-60.

34. Bouanga JC, Mouélé R, Préhu C, Wajcman H, Feingold J, Galactéros F. Glucose-6-phosphate dehydrogenase deficiency and homozygous sickle cell disease in Congo. Hum Hered. 1998;48(4):192-7.

35. el-Hazmi MA, Warsy AS, Bahakim HH, al-Swailem A. Glucose-6-phosphate dehydrogenase deficiency and the sickle cell gene in Makkah. Saudi Arabia J Trop Pediatr. 1994;40(1):12-6.

36. Dowling MM, Quinn CT, Rogers ZR, Buchanan GR. Acute silent cerebral infarction in children with sickle cell anemia. Pediatr Blood Cancer. 2010; 54(3):461-4.

37. Belisário AR, Silva CM, Velloso-Rodrigues C, Viana MB. Genetic, laboratory and clinical risk factors in the development of overt ischemic stroke in children with sickle cell disease. Hematol Transfus Cell Ther. 2018:40(2):16681.

38. Jordan LC, Casella JF, DeBaun MR. Prospects for primary stroke prevention in children with sickle cell anaemia. Br J Haematol. 2012;157(1):14-25.

39. Sclafani S, Pecoraro A, Agrigento V, Troia A, Di Maggio R, Sacco M, et al. Study on hydroxyurea response in hemoglobinopathies patients using genetic markers and liquid erythroid cultures. Hematol Rep. 2016;8(4):6678.

40. Bauer DE, Orkin SH. Update on fetal hemoglobin gene regulation in hemoglobinopathies. Curr Opin Pediatr. 2011;23(1):1-8.

41. Pegelow $\mathrm{CH}$, Adams RJ, McKie V, et al. Risk ofrecurrent stroke in patients with sickle cell disease treated with erythrocyte transfusions. J Pediatr. 1995; 126(6):896-9.

42. Cox SE, Makani J, Newton CR, Prentice AM, Kirkham FJ. Hematological and Genetic Predictors of Daytime Hemoglobin Saturation in Tanzanian Children with and without Sickle Cell Anemia. ISRN Hematol. 2013;2013:472909. .

43. Tarer V, Etienne-Julan M, Diara JP, Belloy MS, Mukizi-Mukaza M, Elion J, et al. Sickle cell anemia in Guadeloupean children: pattern and prevalence of acute clinical events. Eur J Hematol. 2006;76(3):193-9.

44. Belisário AR, Rodrigues CV, Martins ML, Silva CM, Viana MB. Coinheritance of a -thalassemia decreases the risk of cerebrovascular disease in a cohort of children with sickle cell anemia. Hemoglobin. 2010;34:516-29.

45. Pandey S, Pandey S, Mishra RM, Sharma M. Genotypic influence of adeletions on the phenotype of Indian sickle cell anemia patients. Korean J Hematol. 2011:46:192-5.

46. Alsultan A, Aleem A, Ghabbour H, AlGahtani FH, Al-Shehri A. Sickle cel disease subphenotypes in patients from South Western province of SaudiArabia. J Pediatr Hematol Oncol. 2012;34:79-84.

47. Rumaney MB, Ngo Bitoungui VJ, Vorster AA, Ramesar R, Kengne AP, Ngogang J, et al. The co-inheritance of alpha-thalassemia and sickle cell anemia is associated with better hematological indices and lower consultations rate in Cameroonian patients and could improve their survival. PLoS One. 2014;9(6):e100516.

48. Makani J, Menzel S, Nkya S, Cox SE, Drasar E, Soka D, et al. Genetics of fetal hemoglobin in Tanzanian and British patients with sickle cell anemia. Blood. 2011;117(4):1390-2.

49. Green NS, Barral S. Emerging science of hydroxyurea therapy for pediatric sickle cell disease. Pediatr Res. 2014;75(1-2):196-204

50. Friedrisch JR, Sheehan V, Flanagan JM, Baldan A, Summarell CC, Bittar CM, et al. The role of BCL11A and HMIP-2 polymorphisms on endogenous and hydroxyurea induced levels of fetal hemoglobin in sickle cell anemia patients from southern Brazil. Blood Cells Mol Dis. 2016;62:32-7.

51. Creary LE, Ulug P, Menzel S, McKenzie CA, Hanchard NA, Taylor V, et al. Variation on chromosome 6 influences $F$ cell levels in healthy individuals of African descent and HbF levels in sickle cell patients. PLoS One. 2009:4(1): e4218.
52. Wonkam A, Ngo Bitoungui VJ, Vorster AA, Ramesar R, Cooper RS, Tayo B, et al. Association of variants at BCL11A and HBS1L-MYB with hemoglobin F and hospitalization rates among sickle cell patients in Cameroon. PLoS One. 2014;9(3):e92506.

53. Farrell JJ, Sherva RM, Chen Z-Y, Luo HY, Chu BF, Ha SY, et al. A 3-bp deletion in the HBS1L-MYB intergenic region on chromosome $6 \mathrm{q} 23$ is associated with HbF expression. Blood. 2011;117(18):4935-45.

54. Stadhouders R, Aktuna S, Thongjuea S, Aghajanirefah A, Pourfarzad F, van ljcken W, et al. HBS1L-MYB intergenic variants modulate fetal hemoglobin via long-range MYB enhancers. J Clin Invest. 2014;124(4):1699-710.

55. Lettre G, Sankaran VG, Bezerra MA, Araújo AS, Uda M, Sanna S, et al. DNA polymorphisms at the BCL11A, HBS1L-MYB, and beta-globin loci associate with fetal hemoglobin levels and pain crises in sickle cell disease. Proc Natl Acad Sci U S A. 2008;105(33):11869-74.

56. Danjou F, Francavilla M, Anni F, Satta S, Demartis FR, Perseu L, et al. A genetic score for the prediction of beta-thalassemia severity. Haematologica. 2015;100(4):452-7.

57. Galarneau G, Palmer CD, Sankaran VG, Orkin SH, Hirschhorn JN, Lettre G, et al. Fine-mapping at three loci known to affect fetal hemoglobin levels explains additional genetic variation. Nat Genet. 2010;42(12):1049-955.

58. Steinberg MH. Genetic etiologies for phenotypic diversity in sickle cell anemia. Sci World J. 2009:9:46-67.

59. Bernaudin F, Verlhac S, Chevret S, Torres M, Coic L, Arnaud C, et al. G6PD deficiency, absence of alpha-thalassemia, and hemolytic rate at baseline are significant independent risk factors for abnormally high cerebral velocities in patients with sickle cell anemia. Blood. 2008;112:4314-7.

60. Joly P, Pondarré C, Bardel C, Francina A, Martin C. The alpha-globin genotype does not influence sickle cell disease severity in a retrospective cross-validation study of the pediatric severity score. Eur J Haematol. 2012 88(1):61-7.

\section{Publisher's Note}

Springer Nature remains neutral with regard to jurisdictional claims in published maps and institutional affiliations.

Ready to submit your research? Choose BMC and benefit from:

- fast, convenient online submission

- thorough peer review by experienced researchers in your field

- rapid publication on acceptance

- support for research data, including large and complex data types

- gold Open Access which fosters wider collaboration and increased citations

- maximum visibility for your research: over $100 \mathrm{M}$ website views per year

At $\mathrm{BMC}$, research is always in progress.

Learn more biomedcentral.com/submissions 